\title{
Gimnospermas no Parque Ibirapuera, São Paulo, SP, Brasil
}

\author{
André Luiz Gaglioti ${ }^{1,3}$ e Ricardo José Francischetti Garcia ${ }^{2}$
}

Recebido: 20.01.2014; aceito: 18.09.2014

\begin{abstract}
Gymnosperms in the Parque Ibirapuera, São Paulo, São Paulo State, Brazil). Gymnosperms include vascular plants with seeds not enclosed within fruits. Recent molecular studies support the monophyly of extant Gymnosperms. It comprises a group of species widely used for economic and ornamental purposes. Nevertheless, there are a few studies on this group in Brazil. In the present study we carried out a survey of the species and counted specimens occurring in Ibirapuera Park, São Paulo, São Paulo State, Brazil. An identification key to the species of the Park and descriptions for each species were prepared. We recorded 20 species of Gymnosperms in the park, belonging to 13 genera in five families and registered 352 individuals spread over 35 sectors of the park. Ibirapuera Park showed the highest number of species of Gymnosperms, in comparison with other surveys in the municipality, in addition to presenting six species as the first recorded occurrence, demonstrating the importance of this site for conservation.
\end{abstract}

Keywords: conifers, conservation, cycads, survey, taxonomy

RESUMO - (Gimnospermas no Parque Ibirapuera, São Paulo, SP, Brasil). As Gimnospermas incluem as plantas vasculares com sementes não inseridas no interior de frutos. Recentes estudos moleculares corroboram para a monofilia das Gimnospermas atuais. Constituem um grupo de espécies amplamente utilizadas para fins econômicos e ornamentais. Contudo, há poucos estudos sobre esse grupo no Brasil. No presente estudo foi realizado o levantamento das espécies e contagem de espécimes ocorrentes no Parque Ibirapuera, São Paulo, SP, Brasil. Foi elaborada uma chave dicotômica de identificação para as espécies do Parque e descrição para cada uma das espécies. Foram encontradas 20 espécies de Gimnospermas, pertencendo a 13 gêneros, em cinco famílias. Registraram-se 352 indivíduos distribuídos por 35 setores do Parque. O Parque Ibirapuera apresentou o maior número de espécies de Gimnospermas, em comparação com outros levantamentos realizados no município, além de apresentar seis espécies como primeira ocorrência registrada, demonstrando a importância deste local para a conservação. Palavras-chave: cicas, coníferas, conservação, levantamento, taxonomia

\section{Introdução}

As Gimnospermas compreendem um grupo que abrange as plantas vasculares com sementes não inseridas no interior de frutos. Estima-se que o ancestral das gimnospermas tenha surgido no fim do período Devoniano (Doley 2006). Tradicionalmente as gimnospermas são tradadas por diferentes autores como um grupo parafilético, organizado em quatro linhagens: Cycadales, Ginkgoaceae, Coniferales e Gnetales. No entanto, os estudos moleculares corroboram para a monofilia das Gimnospermas atuais (Chaw et al. 2000, Rydin et al. 2002, Burleigh \& Mathews 2004, Xi et al. 2013).

A maior diversidade do grupo concentra-se no hemisfério Norte em regiões de clima temperado, onde formam extensas florestas. No Brasil são reconhecidos sete gêneros e 30 espécies, pertencentes a seis famílias, sendo Pinaceae representada apenas por espécies subespontâneas (Souza 2012). Trata-se de um grupo de grande importância econômica e de largo emprego no paisagismo, contudo há carência de informações morfológicas das espécies aqui descritas. Podem ser destacados os trabalhos de Marchiori (1996), com chave e descrição para espécies nativas e exóticas do Rio Grande do Sul; e os trabalhos de divulgação de Lorenzi \& Souza (2001) e Lorenzi (2002, 2003) com descrições sucintas e fotos de espécies arbóreas e arbustivas, nativas e exóticas. Para a conservação dos campos naturais, Pinus elliottii é uma espécie problemática, visto seu comportamento como invasora (Garcia \& Pirani 2005).

1. Instituto de Botânica, Núcleo de Pesquisa Curadoria do Herbário SP, Av. Miguel Stéfano 3687, 04301-012 São Paulo, SP, Brasil. Trabalho de Conclusão de Curso em Ciências Biológicas, Unisa - Universidade de Santo Amaro

2. Herbário Municipal de São Paulo (PMSP), Av. IV Centenário, 1268, Parque Ibirapuera, portão 7A, 04030-000, São Paulo, SP, Brasil

3. Autor para correspondência: agaglioti@gmail.com 
Para o município de São Paulo, considerando-se as espécies nativas e exóticas, são registradas 55 espécies de Gimnospermas conforme o banco de dados de coletas e bibliografia do Herbário Municipal (PMSP), o que representa cerca de $1 \%$ da flora vascular registrada. Considerando o banco de dados do SISGAU (Sistema de Gerenciamento da Arborização Urbana da Prefeitura do Município de São Paulo). Havia o registro de seis espécies de Gimnospermas cadastradas em vias públicas, em um universo de 225 espécies (dados de julho de 2012), o que corresponde a 2,6\% das espécies.

Dentre as áreas verdes públicas urbanas do município de São Paulo, destaca-se o Parque Ibirapuera, como marco paisagístico, simbólico, turístico e ambiental da cidade. Inaugurado em 21 de agosto de 1954, durante as comemorações do IV Centenário de São Paulo, o Parque Ibirapuera foi concebido pelos arquitetos Oscar Niemeyer, Ulhôa Cavalcanti, Zenon Lotufo, Eduardo Knesse de Mello, Ícaro de Castro Mello, além do paisagista Augusto Teixeira Mendes. É um dos parques mais procurados pela população paulistana, sendo uma das mais importantes áreas verdes e de lazer da cidade (SVMA 2012). Atualmente podem ser reconhecidos setores de uso esportivo, cultural e ambiental.

O presente trabalho teve como objetivos inventariar e descrever as espécies de Gimnospermas ocorrentes no Parque Ibirapuera, São Paulo, elaborar uma chave de identificação para as espécies e realizar considerações sobre sua ocorrência no Parque.

\section{Material e métodos}

O Parque Ibirapuera localiza-se no Município de São Paulo, distrito de Moema, com coordenadas $23^{\circ} 35^{\prime} 11^{\prime \prime S}$ e 46³9'26"W. Tem área total de 158,4 ha, topografia suave a predominantemente plana, várias ruas delimitando setores de tamanhos diferentes e diversos tipos de uso (figura 1). A vegetação é predominantemente introduzida, com espécies nativas e exóticas, composta por gramados, bosques e jardins, além de vegetação ruderal e de brejo junto ao córrego do Sapateiro; este e o córrego Boa Vista foram represados em um sistema de lagos.

Foi realizada uma análise do espaço físico do Parque, determinando os setores a serem estudados, por meio de mapas e reconhecimento em campo. Foram enumeradas 60 áreas em todo o Parque, sendo incluídas as áreas do Viveiro Manequinho Lopes e do Mausoléu ao Soldado Constitucionalista de 1932, e excluindo os setores sem acesso público gratuito como o Pavilhão Japonês (figura 2).

Amostras das plantas foram coletadas de agosto de 2004 a agosto de 2005, sendo herborizadas segundo os procedimentos técnicos recomendados por Fidalgo \& Bononi (1989). O material testemunho encontra-se depositado no Herbário Municipal de São Paulo (PMSP).

Para a descrição de cada espécie foram utilizadas características vegetativas e reprodutivas, como altura (estimada por comparação com uma altura referencial), DAP (diâmetro a 1,30 $\mathrm{m}$ de altura do solo), características morfológicas do súber, padrões de ramificação do tronco e ramos, formato da copa, morfologia das folhas e estruturas associadas, coloração das estruturas reprodutivas, períodos fenológicos, presença de resina, entre outras. A partir das descrições foi elaborada uma chave para a identificação das espécies do Parque.

Foi realizada a contagem de todos os espécimes de cada espécie, por setor do Parque.

A análise florística deu-se a partir da riqueza (número) de espécies por família e comparação com levantamentos florísticos realizados no município de São Paulo, com presença de Gimnospermas (Hoehne et al. 1941, Hashimoto 1988, Garcia 1999a, Garcia 1999b, Garcia \& Pirani 2001, Garcia \& Pirani 2005, Lagoa 2008, Souza et al. 2009, Almeida et al. 2010) e no SISGAU.

\section{Resultados e Discussão}

\section{Folhas pinadas}

2. Folíolos com 9-26 $\times 0,8-13 \mathrm{~cm}$ 14. Cycas circinalis

2. Folíolos com 3-18 $\times 0,4-0,5 \mathrm{~cm}$ 15. Cycas revoluta

1. Folhas simples

3. Folhas imbricadas, com filotaxia oposta-cruzada ou verticilada

4. Folhas verticiladas, 3 por verticilo 5. Callitris oblonga

4. Folhas com filotaxia oposta-cruzada

5. Folhas laterais e faciais monomórficas 
6. Copa cônica, com ramificações laxas; folhas 1,2-2,3 mm compr. 10. Cupressus macnabiana

6. Copa colunar, com ramificações congestas; folhas $0,7-1 \mathrm{~mm}$ compr. 11. Cupressus sempervivens

5. Folhas laterais e faciais heteromórficas

7. Folhas de cor uniforme, sem marcas de cera esbranquiçada 12. Platycladus orientalis

7. Folhas com marcas de cera esbranquiçada

8. Folhas com odor cítrico ou málico quando maceradas 13. Thuja occidentalis

8. Folhas sem odor característico quando maceradas

9. Folhas com ápice agudo a acuminado, dotadas de glândulas translúcidas conspícuas

6. Chamaecyparis lawsoniana

9. Folhas com ápice obtuso, dotadas de glândulas negras na face abaxial

7. Chamaecyparis obtusa

3. Folhas nunca imbricadas, filotaxia alterna ou oposta

10. Braquiblastos

11. Fascículo com 2 a 3 acículas

12. Acículas com 2,5-10 cm compr.

19. Pinus thunbergii

12. Acículas com 13-25,5 cm compr 17. Pinus elliottii

11. Fascículo com 5 a 20 acículas

13. Fascículo com 5 acículas

18. Pinus oocarpa

13. Fascículo com 12 a 20 acículas 16. Cedrus deodara

10. Folhas solitárias

14. Folhas lineares a aciculares, arqueadas em direção ao ramo

8. Cryptomeria japonica

14. Folhas nunca lineares ou aciculares, não arqueadas em direção ao ramo

15. Filotaxia oposta a suboposta

1. Agathis robusta

15. Filotaxia alterna

16. Folhas monomórficas

17. Ramos com escamas terminais, oval-triangulares

20. Podocarpus lambertii

17. Ramos sem escamas terminais

18. Copa cônica nos indivíduos jovens e corimbosa na maturidade, ramos

secundários dispostos espiraladamente nos ramos primários

2. Araucaria angustifolia

18. Copa piramidal a irregular, ramos secundários com disposição dística nos ramos primários

9. Cunninghamia lanceolata

16. Folhas heteromórficas

19. Copa piramidal; ramos com crescimento intermitente, 2 a 7 sequências de crescimento .. 3. Araucaria bidwillii

19. Copa colunar; ramos sem crescimento intermitente

4. Araucaria heterophylla

\section{Araucariaceae}

1. Agathis robusta (C. Moore ex F. Muell.) F.M. Bailey, Syn. Queensl. F1.: 498. 1883.

Nomes populares: kauri, kauri-australiano, pinheiro-kauri.

Árvore $16 \mathrm{~m}$ alt., DAP $24 \mathrm{~cm}$, copa irregular. Tronco colunar, livre de ramagem na maior parte de seu comprimento. Ramos primários delgados e patentes. Súber descamando-se em lâminas irregulares finas, marrom-avermelhadas. Folhas ovadas a elípticas, 4,5-9,8 × 1,2-3 cm, monomórficas, verde-escuras na face adaxial e verde-claras na face abaxial, opostas a subopostas, coriáceas, glabras, sésseis, ápice agudo a obtuso, margem levemente revoluta, base atenuada.
Material examinado: BRASIL. São PAUlo: São Paulo, Parque Ibirapuera, 6-I-2005, A.L.Gaglioti 21 (PMSP).

Distribuição geográfica: Espécie nativa da Austrália (Queensland) e na Nova Guiné Ocidental (Marchiori 1996). No Parque Ibirapuera foi registrada no setor 10. No município de São Paulo foi registrada também no Parque da Luz (Hashimoto 1988).

2. Araucaria angustifolia (Bertol.) Kuntze, Revis. Gen. P1. 3(3): 375. 1898.

Nomes populares: araucária, pinheiro-do-paraná, pinho-do-paraná, curi.

Árvore 4-18 m alt., DAP 16-55 cm, copa cônica nos indivíduos jovens, posteriormente ramos mais 
velhos ascendentes, copa corimbosa na maturidade. Ramos primários verticilados, ramos secundários alternos, caducos, agrupados no ápice dos ramos primários. Súber espesso acinzentado, áspero e profundamente fendilhado, desprendendo-se em placas regulares e em lâminas na parte superior do tronco, próximo à copa. Folhas oval-lanceoladas a estreito-lanceoladas, 8-42 × 3-12 mm, monomórficas, verdes ou glaucas, espiraladas, coriáceas, glabras, quinadas na face abaxial, estômatos alinhados longitudinalmente, ápice agudo, pungente, margem inteira, base decorrente côncava.

Material examinado: BRASIL. São Paulo: São Paulo, Parque Ibirapuera, 12-I-2005, A.L.Gaglioti 48 (PMSP).

Distribuição geográfica: Espécie nativa do Brasil (Dos Estados de Minas Gerais e Rio de Janeiro até Rio Grande do Sul), Paraguai e Argentina (Garcia 2002). No Parque Ibirapuera foi registrada nos setores 10, 41, 55, 56, 57, 58. No município de São Paulo foi registrada também no SISGAU e nos parques Aclimação, Anhanguera, Carmo, Guarapiranga, Lina e Paulo Raia, Luz, Nabuco, Piqueri, Previdência, Vila dos Remédios (Hashimoto 1988), Independência (Almeida et al. 2010), Dr. Fernando Costa (Lagoa 2008), Fontes do Ipiranga (Garcia 1999a), Jaraguá (Souza et al. 2009) e Jardim Botânico (Hoehne et al. 1941).
3. Araucaria bidwillii Hook., London J. Bot. 2: 503-506, t.18, 19, f.1. 1843.

Nomes populares: bunya-bunya, pinheiro-bunyabunya.

Árvore 6,5-18 m alt., DAP 31-102 cm, copa piramidal. Ramos primários verticilados, ramos secundários opostos a subopostos, caducos, agrupados no ápice dos ramos primários, com crescimento intermitente, 2 a 7 sequências de crescimento, 1,8-8,5 cm compr. cada sequência. Súber espesso, áspero, desprendendo-se em lâminas finas, presença de resina esbranquiçada. Folhas dispostas espiraladamente, verde-escuras a verdeclaras, coriáceas, glabras, rijas, sésseis, presença de estômatos arranjados em linhas longitudinais na face abaxial, ápice agudo, pungente, margem inteira, base truncada, heteromórficas. Folhas maiores lanceoladas, $2-4,2 \times 0,5-1 \mathrm{~cm}$. Folhas menores triangulares a lanceoladas, 3-8 × 0,3-0,5 mm. Estróbilos femininos globosos a ovoides, $15-21 \times 13-18 \mathrm{~cm}$; raque cilíndrica, $6-9,5 \times 2,5-4,5 \mathrm{~cm}$, com cicatrizes losangulares da inserção das escamas ovulíferas; 60-82 escamas ovulíferas por estróbilo, escama ovulífera concrescida ao óvulo, 6-8,2 $\times 4-6,5 \mathrm{~cm}$, triangular, com rudimentos de asas, presença de resina branca, ápice triangular, apiculado, lenhoso, recurvo, pungente, com dilatação
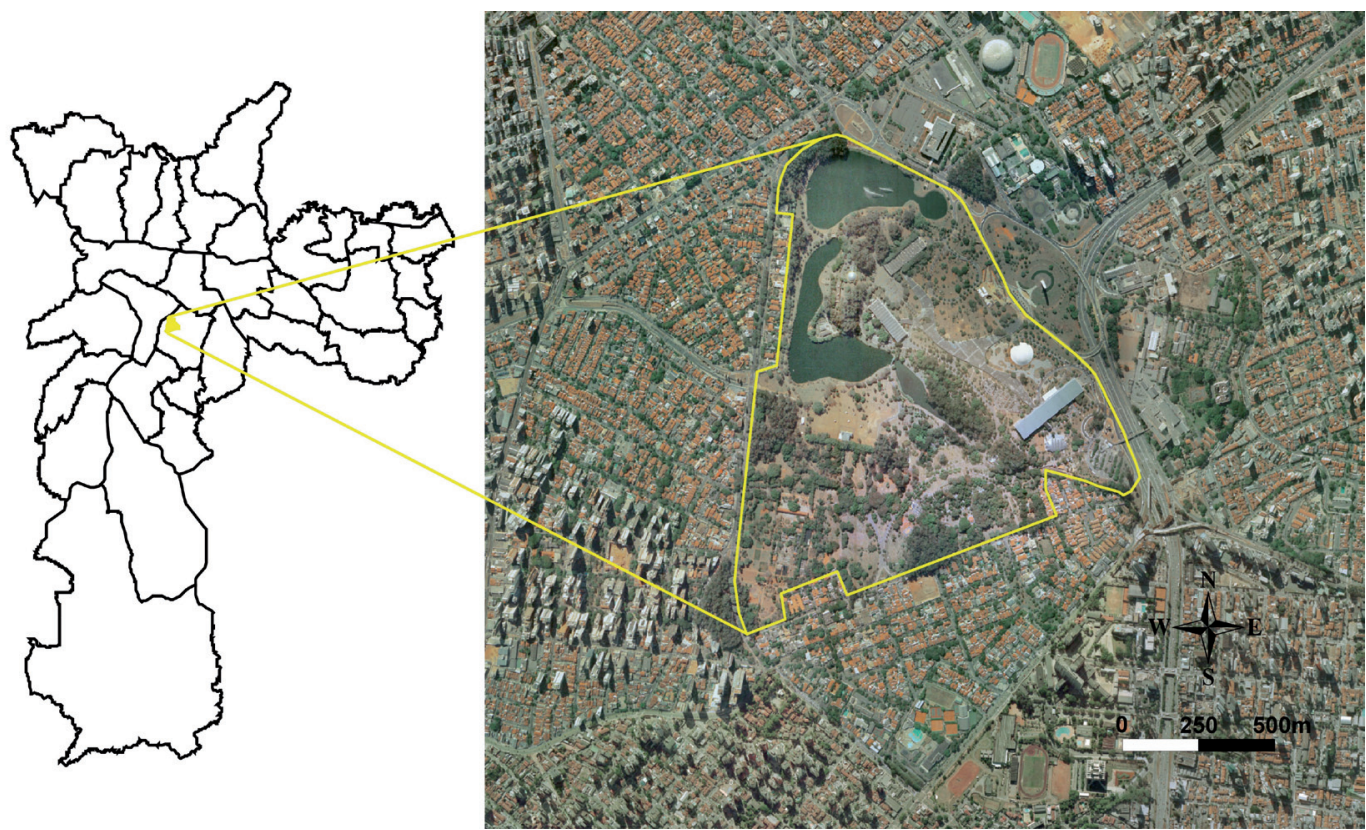

Figura 1. Município de São Paulo com subprefeituras e localização do Parque Ibirapuera, SP, Brasil. Ortofoto MSP 2001, escala de voo 1:25.000. Fonte: acervo SIGMA-SVMA-PMSP.

Figure 1. City of São Paulo with subprefectures and location of Parque Ibirapuera, São Paulo State, Brazil. Orthophoto MSP 2001, flight scale 1:25,000. Source: SIGMA-SVMA collection - PMSP. 
proeminente logo abaixo, verde-escuro a verde próximo ao ápice e marrom nas asas e semente. Sementes piriformes, 2-4,5 $\times 1-1,8 \mathrm{~cm}$, brancas.

Material examinado: BRASIL. S̃̃o PAULO: São Paulo, Parque Ibirapuera, 6-I-2005, A.L.Gaglioti 20 (PMSP).

Distribuição geográfica: Espécie nativa da Austrália (Queensland) (Marchiori 1996). No Parque Ibirapuera foi registrada nos setores 10, 11, 20, 30, 41, 56, 57 . No município de São Paulo foi registrada também nos parques Guarapiranga, Luz (Hashimoto 1988), Dr. Fernando Costa (Lagoa 2008) e Jardim Botânico (Hoehne et al. 1941).

4. Araucaria heterophylla (Salisb.) Franco, Anais Inst. Super. Agron. 19: 11-12. 1952.
Nome popular: pinheiro-de-norfolk.

Árvore 5-18 m alt., DAP 32-75 cm, copa piramidal. Ramos primários verticilados, ramos secundários espiralados. Súber espesso, áspero, desprendendo-se em lâminas irregulares com até $8 \mathrm{~cm}$ compr., presença de resina esbranquiçada e translúcida. Folhas dispostas espiraladamente, arqueadas em direção ao ramo, verde-escuras a verde-claras, glabras, sésseis, presença de estômatos esbranquiçados, ápice agudo, margem inteira, base decorrente, heteromórficas. Folhas juvenis ovais a estreitolanceoladas, 1,5-3,5 × 1-2 mm. Folhas adultas ovadas a estreito-lanceoladas, 6-12 × 1-3 mm. Estróbilos femininos imaturos, ovoides, 3,5-4 × 2,3-2,5 cm,

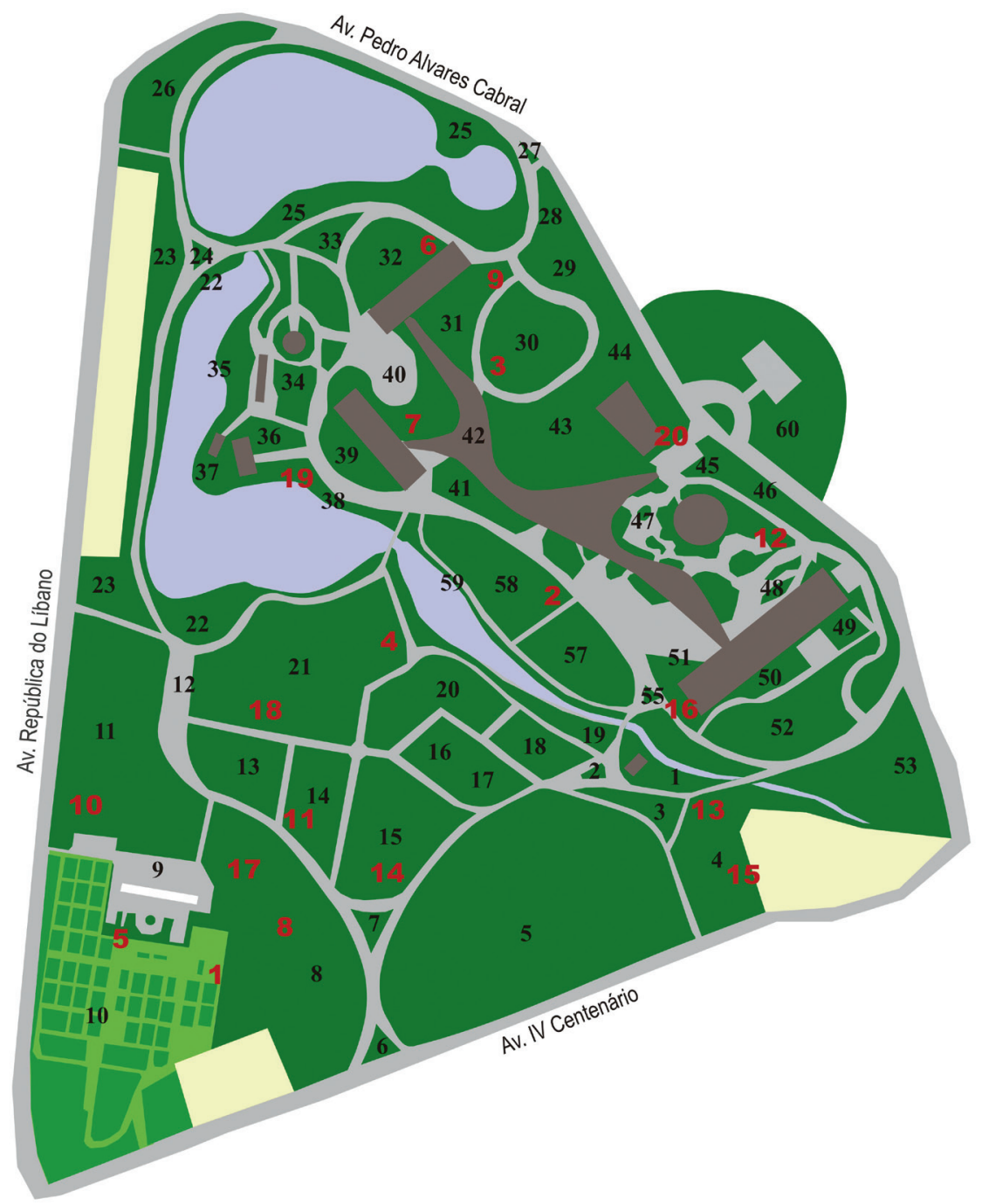

Figura 2. Mapa ilustrativo do Parque Ibirapuera, São Paulo, SP, Brasil. Números pretos: setores. Números vermelhos: número da espécie com localização de um espécimen para roteiro de visitação (numeração conforme texto).

Figure 2. Map illustrating of Parque Ibirapuera, São Paulo, São Paulo State, Brazil. Black numbers: sectors. Red numbers: number of species with location of a specimen for guide visitation (numbers according to the text). 
104-115 escamas ovulíferas por estróbilo, escama ovulífera concrescida ao óvulo, 1,0-2,3 $\times 0,5-1 \mathrm{~cm}$, presença de resina translúcida, ápice agudo, estreitotriangular, lenhoso, recurvo, pungente, verdes a verdeclaros.

Material examinado: BRASIL. São PAULO: São Paulo, Parque Ibirapuera, 30-XII-2004, A.L.Gaglioti 17 (PMSP); idem, 10-I-2005, A.L.Gaglioti 37 (PMSP).

Distribuição geográfica: Espécie nativa da Ilha Norfolk (Oceania) (Marchiori 1996). No Parque Ibirapuera foi registrada nos setores $2,4,10,11,18$, 21, 31, 39, 42, 43, 47. No município de São Paulo foi registrada também nos parques Aclimação e Piqueri (Hashimoto 1988), Independência (Almeida et al. 2010), Dr. Fernando Costa (Lagoa 2008) e Jardim Botânico (Hoehne et al. 1941).

\section{Cupressaceae}

5. Callitris oblonga Rich. \& A. Rich., Comm. Bot. Conif. Cycad. 49 t. 18, f. 2. 1826.

Nomes populares: cipreste-da-tasmânia, calitris.

Árvore $14 \mathrm{~m}$ alt., copa cônica. Tronco 3-ramificado a $40 \mathrm{~cm}$ da base, presença de calosidades avermelhadas por toda extensão do tronco, resinífero. Ramos primários ascendentes, curtos, ramos secundários ascendentes, congestos, ramos de terceira e quarta ordem cilíndricos, delgados, com ramificação dicotômica. Súber marrom a marrom-avermelhado, profundamente fissurado, desprendendo-se em lâminas longitudinais, espessas e irregulares. Folhas imbricadas, 3 por verticilo, escamiformes, monomórficas, concrescentes, adpressas ao ramo, 2,5-4,2 × 0,5-0,8 mm, carenadas, glabras, verdeclaras a verde-azuladas, ápice triangular agudo, finamente serrilhada, margem inteira, base decorrente. Estróbilos masculinos globosos, cilíndricos ou oblongos, 2,3-4,5 × 1-2,2 mm, verde-claros (imaturos) a amarelados (maduros), 15-34 microsporófilos por estróbilo, microsporófilos, ovados, imbricados, ápice agudo, 3-4 microsporângios por microsporófilo. Estróbilos femininos ovoides, 1-2,3 × 1-1,8 cm, ovoides, solitários ou agrupados, terminais, sésseis a subsésseis, 6 escamas por estróbilo, escamas rugosas, marrom-acinzentadas, lenhosas, múcron diminuto no ápice, fundidas na base, 3 escamas maiores, 1-1,9 × 0,5-0,7 mm, 3 escamas menores, 5-8 $\times$ 3-4 mm, 4-5 sementes por escama. Sementes ovais, $4-7 \times 4,5-8 \mathrm{~mm}$, marrom-avermelhadas, com asas rudimentares.
Material examinado: BRASIL. S̃̃o PAULo: São Paulo, Parque Ibirapuera, 8-IX-2004, A.L.Gaglioti 1 (PMSP).

Distribuição geográfica: Espécie nativa da Austrália (Tasmânia) (Dallimore \& Jackson 1966). No Parque Ibirapuera foi registrada no setor 10, sendo o único registro publicado no município de São Paulo.

6. Chamaecyparis lawsoniana (A. Murray) Parl., Ann. Mus. Imp. Fis. Firenze 1: 181. 1864.

Nomes populares: cipreste-escaravelho, ciprestealumi, alumi.

Árvore 4,5-7 m alt., DAP 15-21 cm, copa piramidal. Ramos primários ásperos, escamosos, dispostos horizontalmente, ramos secundários congestos $\mathrm{e}$ compactos, dispostos em planos distintos, horizontais a ascendentes. Súber marrom-avermelhado, estriado longitudinalmente, desprendendo-se em placas laminares longitudinais. Folhas imbricadas, opostocruzadas, verde-escuras a verde-azuladas, glabras, com marcas de cera esbranquiçadas, concentradas próximas à base, dotadas de glândula translúcida conspícua, ápice agudo a agudíssimo, margem inteira, base decorrente, escamiformes, heteromórficas. Folhas laterais, 1,8-3,2 × 0,6-0,8 mm, carenadas, sobrepondo levemente às folhas faciais. Folhas faciais, 1,2-2,7 × 0,6-1 mm, oblongas.

Material examinado: BRASIL. São Paulo: São Paulo, Parque Ibirapuera, 6-I-2005, A.L.Gaglioti 22 (UNISA); idem, 14-I-2005, A.L.Gaglioti 55 (PMSP).

Distribuição geográfica: Espécie nativa dos Estados Unidos (Oregon e Califórnia) (Marchiori 1996). No Parque Ibirapuera foi registrada nos setores 10, 32. Sem outros registros publicados para o município de São Paulo, embora seja muito cultivada.

7. Chamaecyparis obtusa (Siebold \& Zucc.) Endl., Syn. Conif. 63. 1847.

Nomes populares: cipreste-dourado, pinheirodourado, tuia-europeia.

Árvore 2,5-7,5 m alt., DAP 6-14 cm, copa cônica, globosa a irregular, copa com ramagem densa. Ramos primários patentes, compactos, ramos secundários menores achatados, com ramificação dicotômica, levemente pendentes ou ascendentes, distalmente; folhas amarelas próximo às extremidades dos ramos secundários. Súber marrom-avermelhado, desprendendo-se em lâminas delgadas. Folhas imbricadas, oposto-cruzadas, verde-escuras, verdes ou 
amareladas, glabras, com glândulas na face abaxial, arredondadas, sulcadas, pretas, marcas de cera esbranquiçada na face abaxial, ápice obtuso, margem inteira, base atenuada, escamiformes, heteromórficas. Folhas laterais maiores, naviculares, 3-4 × 1-1,5 mm. Folhas faciais menores, triangulares, 1-2 $\times 1-1,3 \mathrm{~mm}$.

Material examinado: BRASIL. São PaUlo: São Paulo, Parque Ibirapuera, 7-I-2005, A.L. Gaglioti 33 (PMSP); idem, 14-I-2005, A.L.Gaglioti 56 (PMSP); idem, 17-I-2005, A.L.Gaglioti 58 (PMSP).

Distribuição geográfica: Espécie nativa do Japão (Lorenzi 2003). No Parque Ibirapuera foi registrada nos setores 10, 22, 40, sem outros registros publicados para o município de São Paulo.

8. Cryptomeria japonica (Thunb. ex L.f.) D. Don, Trans. Linn. Soc. London 18: 167, pl. 13, f.1. 1839.

Nomes populares: cedro-japonês, pinheiro-do-japão.

Árvore 1,5-12 m alt., DAP 9-30 cm, copa piramidal a colunar. Ramos primários verticilados, patentes, pendentes ou ascendentes. Súber marromavermelhado, fissurado e longitudinalmente desprendendo lâminas longitudinais. Folhas lineares, heteromórficas, 4-12 × 0,8-1,2 mm, espiraladas, 3-4 anguladas, arqueadas em direção ao ramo, verdes a verde-glaucas, glabras, rijas, com estômatos espalhados por todo o limbo, ápice agudo, margem inteira, base truncada. Estróbilos masculinos ovoides a cilíndricos, solitários ou 3-6 grupos, 5-10 × 2-4 mm, terminais, amarelados, 12-38 microsporófilos por estróbilo, triangulares, com ápice agudo. Estróbilos femininos globosos, 1,2-2,5 × 1-2,3 cm, solitários, terminais a subterminais, verdes a marrons, 20-30 escamas por estróbilo; escamas lenhosas, 6-13 × 2-4 mm, 4 a 5 dentes no ápice. Sementes triangulares, 4-7 × 2-3 mm, com rudimentos de asas, marrom-avermelhadas.

Material examinado: BRASIL. São PAULO: São Paulo, Parque Ibirapuera, 15-VIII-2004, A.L.Gaglioti 3 (PMSP); idem, 10-I-2005, A.L.Gaglioti 38 (PMSP).

Distribuição geográfica: Espécie nativa do Japão e China (Lorenzi 2003). No Parque Ibirapuera foi registrada nos setores $1,4,5,8,10,11,18,23$. No município de São Paulo foi registrada também nos parques Aclimação, Carmo, Guarapiranga, Luz, Nabuco, Piqueri, Previdência, São Domingos, Vila dos Remédios (Hashimoto 1988) e Dr. Fernando Costa (Lagoa 2008).
9. Cunninghamia lanceolata (Lamb.) Hook., Bot. Mag. 54: pl. 2743. 1827.

Nomes populares: pinheiro-chinês, pinheiro-alemão, cuningâmia.

Árvore 9-18 m alt., DAP 39-63 cm, copa piramidal a irregular. Ramos primários verticilados, ramos secundários alternos, com tendência a formar verticilos com a idade, ramos de terceira ordem ternados. Súber marrom, espesso, provido de fissuras longitudinais e desprendendo-se em lâminas irregulares, expondo superfície abaixo, marrom-avermelhada. Folhas lanceoladas, 2,5-5,2 × 0,3-0,5 cm, espiraladas, monomórficas, coriáceas, glabras, face adaxial verde-escura a verde, com duas linhas longitudinais delgadas de estômatos esbranquiçados, face abaxial verde, com nervura central proeminente, dividindo duas faixas estomáticas longitudinais esbranquiçadas, ápice alongado, agudo, margem finamente serreada, base truncada. Estróbilos masculinos agrupados de 8 a 12 por fascículo, $1,5-2,3 \times 0,5-0,8 \mathrm{~cm}$, cilíndricos; 20-56 microsporófilos, com 3 a 4 microsporângios em sua face abaxial, marrom-amarelados, terminais a subterminais. Estróbilos femininos ovoides a globosos, 2-3,5 $\times 2-3 \mathrm{~cm}$, terminais, sésseis, 35-46 escamas por estróbilo; escamas ovadas a arredondadas, coriáceas, com ápice agudo e pungente, margem finamente serreada, verde quando imaturos e marrom nos maduros. Sementes achatadas, 2-5 × 2-4 mm, marromalaranjadas, presença de asa membranácea estreita.

Material examinado: BRASIL. São PAUlo: São Paulo, Parque Ibirapuera, 6-I-2005, A.L.Gaglioti 26(PMSP); idem, 14-I-2005, A.L.Gaglioti 54 (UNISA).

Distribuição geográfica: Espécie nativa da China central e meridional, Taiwan, Vietnã e Laos (Marchiori 1996). No Parque Ibirapuera foi registrada nos setores 10, 31. No município de São Paulo foi registrada também nos parques Luz (Hashimoto 1988), Independência (Almeida et al. 2010) e Dr. Fernando Costa (Lagoa 2008), além de ser cultivada comercialmente na Fazenda Castanheiras (APA Bororé-Colônia).

10. Cupressus macnabiana A. Murray, Edinburgh Philos. J. 1: 293, pl. 11. 1855.

Nome popular: cipreste mac-nab.

Árvore 7,5 m alt., DAP $42 \mathrm{~cm}$, copa cônica. Tronco ramificando-se próximo à base, 3-ramificado. Ramos primários ascendentes, ramificados, em apenas 
um lado do tronco. Ramos secundários cilíndricos, delgados, ascendentes. Súber marrom-acinzentado, desprendendo-se em lâminas esparsas e finas, expondo uma superfície avermelhada. Folhas imbricadas, 1,2-2,3 $\times 0,5-0,8 \mathrm{~mm}$, ovadas a ovado-oblongas, escamiformes, monomórficas, oposto-cruzadas, verdeescuras a verde-azuladas, glabras, glândula conspícua na face abaxial, exsudando resina translúcida, adpressas ao eixo, ápice agudo, margem finamente serreada, base decorrente. Estróbilos masculinos globosos, 2-4 × 1,5-2,5 mm, amarelo-alaranjados, terminais, 10-12 microsporófilos, imbricados.

Material examinado: BRASIL. São PAUlo: São Paulo, Parque Ibirapuera, 28-III-2005, A.L.Gaglioti 64 (PMSP).

Distribuição geográfica: Espécie nativa dos Estados Unidos (Califórnia) (Dallimore \& Jackson 1966). No Parque Ibirapuera foi registrada no setor 11, sem outros registros publicados para o município de São Paulo.

\section{Cupressus sempervirens L., Sp. P1. 2: 1002-1003. 1753.}

Nomes populares: cipreste-italiano, cipreste-domediterrâneo, cipreste-colunar.

Árvore 2,5-15 m de altura, DAP 9-58 cm, copa colunar, copa densa. Ramos primários curtos ascendentes, escamosos, ramos secundários congestos, ascendentes, ramos de terceira e quarta ordem cilíndricos e ascendentes. Súber marrom-acinzentado, desprendendo-se em lâminas finas, levemente fissuradas. Folhas imbricadas, 0,7-1 $\times 0,5-0,7 \mathrm{~mm}$, triangulares a ovado-oblongas, escamiformes, monomórficas, oposto-cruzadas, verde-escuras, glabras, com glândula conspícua na face abaxial, ápice subagudo a obtuso, margem inteira, base decorrente. Estróbilos masculinos globosos a cilíndricos, 2-3,2 × 1-1,8 mm, verdes a verde-amarelados, solitários, terminais, 10-22 microsporófilos, triangulares a ovados, imbricados, fundidos. Estróbilos femininos globosos, 1,8-2,8 × 1,5-2,8 cm, 8-14 escamas lenhosas, umbo poligonal, ápice mucronado, marromacinzentado, terminais a subterminais, solitárias, 12-15 sementes por escama. Sementes achatadas, ovoides a oblongas, 3-6 mm compr., 2-3,5 mm larg., marrom-avermelhadas, com asas rudimentares.

Material examinado: BRASIL. São PAUlo: São Paulo, Parque Ibirapuera, 30-XII-2004, A.L.Gaglioti 15 (UNISA); idem, 30-XII-2004, A.L.Gaglioti 16 (PMSP).
Distribuição geográfica: Espécie nativa da região mediterrânea, sul da Europa e Ásia Menor (Marchiori 1996). No Parque Ibirapuera foi registrada nos setores $8,10,14,24,47,48$. No município de São Paulo foi registrada também no SISGAU e nos parques Carmo, Lina e Paulo Raia, Luz, Piqueri (Hashimoto 1988), Independência (Almeida et al. 2010) e Dr. Fernando Costa (Lagoa 2008), além de ser comumente encontrada na arborização de cemitérios.

12. Platycladus orientalis (L.) Franco, Portugaliae Acta Biol., Sér. B, Sist. Julio Henriques: 33-34. 1949.

Nomes populares: tuia, árvore-da-vida.

Árvore 5-12 m alt., DAP 8-35 cm, copa cônica a irregular. Ramos primários ascendentes, ramos secundários ascendentes, ramos de terceira e quarta ordem dísticos, apresentando no conjunto o formato de leques verticais. Súber delgado, levemente sulcado, marrom-avermelhado, desprendendo-se em finas lâminas longitudinais. Folhas imbricadas, oposto-cruzadas, verde-escuras a verdes, glabras, escamiformes, dotadas de glândula sulcada na face abaxial, presença de estômatos esbranquiçados esparsos, leve aroma resinífero quando esfregadas, ápice agudo, margem inteira, base decorrente, heteromórficas. Folhas laterais, 1,3-2,8 $\times 0,5-0,8 \mathrm{~mm}$, ovadas a oblongas; folhas faciais, 1-2,3 $\times 0,5-0,8 \mathrm{~mm}$, ovadas a oval-triangulares. Estróbilos masculinos ovoides, 1,5-4,5 × 1,5-2 mm, terminais, solitários e amarelados; 16-34 microsporófilos, triangulares, ápice subagudo a obtuso com 5 a 6 microsporângios. Estróbilos femininos ovoides, 1-1,8 $\times 1-1,4 \mathrm{~cm}$, verdes (imaturos) a marrom-avermelhados (maduros); com 6-8 escamas lenhosas, 4 escamas maiores externas, $8-12 \times 6-8 \mathrm{~mm}, 2$ internas e centrais menores, 6-8 $\times 3-4 \mathrm{~mm}, 2$ basais, 3-6 $\times 2-4 \mathrm{~mm}$, obovais, com múcron recurvo próximo ao ápice. Sementes 6-8 por estróbilo feminino, 3-5 mm compr., ovoides, castanhoacinzentadas, ápteras.

Material examinado: BRASIL. São Paulo: São Paulo, Parque Ibirapuera, 3-VIII-2004, A.L.Gaglioti 2 (PMSP); idem, 20-XII-2004, A.L.Gaglioti 12 (UNISA); idem, 7-I-2005, A.L.Gaglioti 27 (PMSP); idem, 10-I-2005, A.L.Gaglioti 35 (PMSP).

Distribuição geográfica: Espécie nativa do leste da Ásia e norte da China (Lorenzi 2003). No Parque Ibirapuera foi registrada nos setores $4,5,9,10,20$, 47, 48. No município de São Paulo foi registrada 
também nos parques Nabuco, Piqueri, São Domingos (Hashimoto 1988) e Independência (Almeida et al. 2010).

\section{Thuja occidentalis L., Sp. P1. 2: 1002. 1753.}

Nomes populares: tuia-do-canadá, árvore-da-vida, árvore-da-vida-americana, cedro-branco, tuia-maçã.

Árvore 5-8,5 m alt., DAP 12-22 cm, copa cônica, densa e muito ramificada. Ramos primários patentes, ramos secundários e de terceira e quarta ordem dísticos apresentando no conjunto formato de leques, horizontais ou pendentes na porção distal. Súber marrom-avermelhado, desprendendo-se em lâminas irregulares. Folhas imbricadas, oposto-cruzadas, verde escuras a verde claras, glabras, concrescentes, marcas de cera esbranquiçada, concentradas próximo à base, com aroma málico ou cítrico quando esfregadas, dotadas de glândula sulcada na face abaxial, ápice agudo, margem inteira, base decorrente, escamiformes, heteromórficas. Folhas laterais, 1,8-2,5 × 0,8-1 mm, ovado-oblongas a carenadas, folhas faciais, $1,2-1,7 \times 0,5-1 \mathrm{~mm}$, ovadas a ovadooblongas.

Material examinado: BRASIL. São PAULO: São Paulo, Parque Ibirapuera, 6-I-2005, A.L. Gaglioti 24 (PMSP); idem, 24-I-2005, A.L.Gaglioti 61 (PMSP).

Distribuição geográfica: Espécie nativa do sudeste do Canadá e norte dos Estados Unidos (Vidaković 1991). No Parque Ibirapuera foi registrada nos setores 4, 10, sem outros registros publicados para o município de São Paulo.

\section{Cycadaceae}

14. Cycas circinalis L., Sp. Pl. 2: 1188. 1753.

Nomes populares: cica, cicas, palmeira-samambaia, sagu.

Planta estipitada, 1,3-6 m alt., DAP $60 \mathrm{~cm}$, folhas verticiladas na região apical do caule, $3-12$ verticilos, os mais internos ascendentes, os mais externos levemente ascendentes, horizontais e/ou pendentes. Tronco cilíndrico, espesso e ereto, eventualmente ramificado. Súber áspero, escamoso, com cicatrizes e remanescentes de restos dos pecíolos, de superfície escura. Folhas pinadas, 12-95 aproximadamente por caule, raque 1-3,20 m compr., com seção transversal plano-convexa, com presença de duas cristas longitudinais na face abaxial, pecíolo $30-90 \mathrm{~cm}$ compr., presença de espinhos, 14-26 em cada lado do pecíolo, 3-5 mm compr.; folíolos 22-142 de cada lado da raque, falciformes, 9-26 ×0,8-1,3 cm, alternos a subopostos, sésseis, glabros, verdes brilhantes a verde-escuros em ambas a faces, nervura central sulcada na face adaxial e proeminente na abaxial, ápice agudo, margem plana a levemente revoluta, inteira, base aguda. Protófilos dispostos em 3-9 verticilos na porção central do ápice do tronco, $6-12 \times 3-5 \mathrm{~cm}$, triangulares, imbricados, com pilosidade amareloalaranjada, ápice caudado, margem inteira, base decorrente. Megasporófilos subterminais, laminares, espessos, 12-32 × 1-2,5 cm, ápice agudo, parte apical dilatada e serreada, margem com recortes nos quais se inserem os óvulos, 1-3 de cada lado da margem, com pilosidade aveludada e amarelo-alaranjada; óvulos imaturos esféricos, verdes a avermelhados, glabros, com presença ou não de cera esbranquiçada por toda superfície, 4-8 $\times$ 5-8 $\mathrm{mm}$.

Material examinado: BRASIL. São PAULO: São Paulo, Parque Ibirapuera, 15-VIII-2004, A.L.Gaglioti 4 (PMSP).

Distribuição geográfica: Espécie nativa da Índia, Filipinas, Indonésia (Sumatra, Java), Madagascar e África tropical (Lorenzi 2003). No Parque Ibirapuera foi registrada nos setores $4,10,15$. No município de São Paulo foi registrada também nos parques Carmo, Luz, Raposo Tavares (Hashimoto 1988), Independência (Almeida et al. 2010) e Jardim Botânico (Hoehne et al. 1941).

15. Cycas revoluta Thunb., Verh. Holl. Maatsch Weetensch. Haarlem 20(2): 424, 426-427. 1782.

Nomes populares: sagu, palmeira-sagu, sagu-dejardim, palma-de-ramos.

Planta estipitada, $60-65 \mathrm{~cm}$ alt., folhas verticiladas na região apical do caule, 1-3 verticiladas, horizontais a levemente ascendentes. Folhas pinadas, 13-17 folhas, raque $56-120 \mathrm{~cm}$ compr., com seção transversal plano-convexa, pecíolo 11-18 $\times 1,3-1,8 \mathrm{~cm}$, presença de espinhos, 13-22, em cada lado do pecíolo, 2-3 mm compr.; 54-87 folíolos de cada lado da raque, lineares a levemente falciformes, 3-18 × 0,4-0,5 cm, verdeescuros na face adaxial e verde-claros na face abaxial, opostos a subopostos, nervura central sulcada na face adaxial e proeminente na face abaxial, rijos, glabros, ápice agudíssimo, margem fortemente revoluta, base decorrente. Protófilos dispostos em 7-12 verticilos na porção central do ápice do tronco, 6-15 × 3-6 cm, triangulares, imbricados, com pilosidade amarelo- 
alaranjada, ápice caudado, margem inteira, base decorrente.

Material examinado: BRASIL. São PAulo: São Paulo, Parque Ibirapuera, 3-VI-2005, A.L. Gaglioti 66 (PMSP).

Distribuição geográfica: Espécie nativa da Indonésia (Java) (Marchiori 1996). No Parque Ibirapuera foi registrada no setor 4. No município de São Paulo foi registrada também nos parques Carmo e Luz (Hashimoto 1988) e Jardim Botânico (Hoehne et al. 1941), além de ser muito utilizada em jardins.

\section{Pinaceae}

16. Cedrus deodara (Roxb. ex D.Don) G. Don, Hort. Brit. 388, no. 23637. 1830.

Nomes populares: cedro-da-índia, cedro-do-himalaia, madeira-dos-deuses.

Árvore 2,5 alt., DAP $7 \mathrm{~cm}$, copa irregular. Tronco levemente oblíquo e resinífero. Ramos primários delgados, longos e pendentes. Braquiblastos cilíndricos ou globosos, 5-8 $\times 3-5 \mathrm{~mm}$, persistentes após a queda das acículas; catafilos ovados a triangulares, imbricados e fundidos, marromescuros. Súber marrom, desprendendo-se em lâminas irregulares. Acículas reunidas em grupos de 12-20 por braquiblasto, 1,2-4,3 × 0,1-0,15 cm, verdeescuras, verde-claras ou verde-azuladas, rijas, glabras, presença de linhas longitudinais de estômatos por toda acícula, seção transversal circular, ápice agudo, pungente, margem inteira, base aguda.

Material examinado: BRASIL. São Paulo: São Paulo, Parque Ibirapuera, 12-I-2005, A.L.Gaglioti 57 (PMSP).

Distribuição geográfica: Espécie nativa da região do Himalaia (Vidaković 1991). No Parque Ibirapuera foi registrada no setor 51. No município de São Paulo foi registrada também no Parque Piqueri (Hashimoto 1988).

17. Pinus elliottii Engelm., Trans. Acad. Sci. St. Louis 4(1): 186-190, pl. 1-3. 1880.

Nomes populares: pinho-comum, pínus, pinheiroamericano.

Árvore 7-19 m alt., DAP 10-51 cm, copa cônica a irregular. Ramos primários longos e ásperos, ascendentes ou pendentes na porção distal, braquiblastos concentrados próximo ao ápice.
Brotos vegetativos ovoide-oblongos a fusiformes, 12-23 × 8-14 mm, formado por catafilos imbricados, subulados, marrom-avermelhados. Súber marrom, marrom-acinzentado ou acinzentado, sulcado, desprendendo-se em placas grandes e largas, com até $7 \mathrm{~cm}$ compr., com presença de resina translúcida e esbranquiçada. Acículas reunidas em grupos de 2 ou 3 por fascículo, 13-25,5 × 0,1-0,2 cm, flexíveis, glabras, verdes a verde-escuras, seção transversal semilunar, ápice agudo, pungente, margem finamente serrilhada, base aguda. Bainha do fascículo, 5-15 × 2-4 mm; escamas fundidas, marromescuras a marrom-claras. Estróbilos masculinos cilíndricos, solitários ou reunidos em grupos de 3 ou 4, terminais ou subterminais, $2-3 \times 0,3-0,5 \mathrm{~cm}$, 25-55 microsporófilos, com 2 microsporângios na face abaxial, castanho-escuros a castanho-claros, grãos de pólen amarelos. Estróbilos femininos cônicos, ovoide-estreitados, ovoides ou ovadooblongos, ligeiramente curvos, 7-13 × 2,5-6,2 cm, axilares, terminais ou subterminais, 63-102 escamas por estróbilo; escama 1,2-2,5 × 0,6-1 cm, lenhosa, com umbo irregularmente rombiforme, quilha saliente, cúspide mucronada, espinho conspícuo e pungente, marrom-claro, marrom-escuro ou marrom-acinzentado. Sementes ovoides, levemente triangulares; núcleo seminífero 3-10 × 3-5 mm; asa oblíqua 7-20 × 4-7 mm, membranácea, marrom-escuro a preta.

Material examinado: BRASIL. S̃̃o PAULO: São Paulo, Parque Ibirapuera, 20-XII-2004, A.L.Gaglioti 13 (PMSP); idem, 11-I-2005, A.L.Gaglioti 45 (UNISA).

Distribuição geográfica: Espécie nativa dos Estados Unidos (Mississipi, Alabama, Geórgia, Carolina do Sul e Flórida) (Marchiori 1996). No Parque Ibirapuera foi registrada nos setores 8, 29, 47. No município de São Paulo foi registrada também no SISGAU e nos parques Aclimação, Luz, Piqueri, Previdência (Hashimoto 1988), Independência (Almeida et al. 2010), Dr. Fernando Costa (Lagoa 2008) e Serra do Mar-Núcleo Curucutu (Garcia \& Pirani 2005), além de ser largamente utilizada em plantios homogêneos, como na APA Capivari-Monos.

18. Pinus oocarpa Schiede ex Schltdl., Linnaea 12: 491-492. 1838.

Nome popular: pinheiro-ovo.

Árvore $12 \mathrm{~m}$ alt., DAP $41 \mathrm{~cm}$, copa irregular. Ramos primários longos e frequentemente tortuosos, 
ascendentes ou pendentes na porção distal, braquiblastos ásperos e escamosos, concentrados próximo ao ápice. Brotos vegetativos ovoide-oblongos a fusiformes, 15-25 × 9-14 mm, catafilos imbricados, subulados, marrom-alaranjados. Súber gretado, acinzentado. Acículas reunidas em grupos de 5 por fascículo, 15-27 × 0,1-0,2 mm, brilhantes, verde-claras, de seção transversal triangular, glabras, ápice agudo, pungente, margem finamente serrilhada, base aguda. Bainhas do fascículo persistentes, 1-2,5 × 0,15-0,2 cm, escamas imbricadas, marrom-escuras a marromavermelhadas. Estróbilos masculinos 9-25 grupos, $1-3,5 \times 0,2-1 \mathrm{~cm}$, ovoides (imaturos) a cilíndricos (maduros), amarelos, com pontos vináceos, terminais a subterminais; 45-105 microsporófilos por estróbilo, ovais, achatados, contendo 2 microsporângios na face abaxial, inseridos em um eixo cilíndrico; brácteas escariosas na base dos estróbilos, ovais a elípticas, 8-15 × 3-5 mm. Estróbilos femininos ovoides a ovoides cônicos, 4,5-6 × 5-7,5 cm, solitários ou em grupos de 2-3, pendentes ou ligeiramente oblíquos, marrons ou marrom-acinzentados, 74-97 escamas por estróbilo; escamas 1,2-1,7 × 0,6-1,2 cm, lenhosas, com ápice reto, quilha transversal pouco saliente, pequeno espinho delgado e deflexo no ápice, 2 sementes por escama. Sementes com núcleo seminífero marromamarelado a acinzentado, 3-12 × 3-6 mm, asa marromescura, 8-18 $\times 3-7 \mathrm{~mm}$.

Material examinado: BRASIL. São PAULO: São Paulo, Parque Ibirapuera, 30-XII-2004, A.L.Gaglioti 18 (PMSP); idem, 29-III-2005, A.L.Gaglioti 65 (PMSP).

Distribuição geográfica: Espécie nativa do oeste e sudoeste do México e Guatemala (Farjon \& Styles 1997). No Parque Ibirapuera foi registrada no setor 21, sem outros registros publicados para o município de São Paulo.

19. Pinus thunbergii Parl., Prodr. 16(2): 388. 1868.

Nomes populares: pinheiro-japonês, pinheiro-preto.

Árvore 2,3 m alt., DAP $6 \mathrm{~cm}$, copa irregular. Tronco tortuoso e levemente inclinado. Ramos primários ascendentes, braquiblastos ásperos, escamosos e ascendentes, concentrados próximo ao ápice. Brotos vegetativos ovoides, agudamente pontudos, 4-7 × 3-4 mm, lisos, formados por catafilos imbricados e fundidos, marrons. Súber fissurado, marrom-acinzentado. Acículas reunidas em grupos de 2 por fascículo, 2,5-10 × 0,1-0,15 cm, verdeescuras, glabras, rijas, torcidas, seção transversal semilunar, com linhas longitudinais de estômatos, ápice agudo, pungente, margem finamente serrilhada, base aguda. Bainha do fascículo, 5-8 × 1,5-2,3 mm; escamas fundidas. Estróbilos masculinos ovoides ou cilíndricos, 8-18 × 3-5 mm, 22-46 microsporófilos por estróbilo, ovados, imbricados, ápice obtuso, amarelos com pontos vináceos.

Material examinado: BRASIL. São PAUlo: São Paulo, Parque Ibirapuera, 17-I-2005, A.L. Gaglioti 60 (PMSP).

Distribuição geográfica: Espécie nativa do norte do Japão e Coreia (Mattos 1998). No Parque Ibirapuera foi registrada no setor 38. No município de São Paulo foi registrada também no Parque Carmo (Hashimoto 1988).

\section{Podocarpaceae}

20. Podocarpus lambertii Klotzsch ex Endl., Syn. Conif. 211. 1847.

Nomes populares: pinheiro-bravo, pinheirinho, pinheiro-branco.

Árvore 3,5-9 m alt., DAP 13-38 cm, copa irregular. Ramos com crescimento intermitente, com cicatrizes de folhas e escamas impressas e unidas em retículos, escamas terminais imbricadas, côncavas, quinadas na face abaxial, oval-triangulares, ápice agudo-obtuso 0,5-2 × 0,5-2 $\mathrm{mm}$. Súber marromacinzentado, com estreitas fissuras e lâminas regulares. Folhas juvenis (protófilos) oblongas a obovais, 5-8 $\times 1-1,8 \mathrm{~mm}$, alternas, sésseis, avermelhadas, ápice arredondado a apiculado. Folhas maduras, lineares a estreito-elípticas, 1-7,2 ×0,1-0,5 cm, alternas, sésseis, verdes em ambas as faces, ápice agudo-pungente, margem inteira, base atenuada, pecioliforme, glabras, nervura sulcada na face adaxial, proeminente na face abaxial, estômatos alinhados longitudinalmente na face abaxial, coriáceas. Plantas dioicas. Estróbilos masculinos cilíndricos, 6-12 × 1-2 mm, 4-9 agrupados, marrons; brácteas oval-arredondadas a triangulares, 0,5-1,2 × 0,3-0,5 mm, 15-35 microsporófilos por estróbilo, com base patente à raque e ápice ascendente 0,8-1,6 × 0,5-0,8 mm; pedúnculo 6-10 mm compr.

Material examinado: BRASIL. São PAulo: São Paulo, Parque Ibirapuera, 7-I-2005, A.L.Gaglioti 28 (UNISA); idem, 12-I-2005, A.L.Gaglioti 51 (PMSP).

Distribuição geográfica: Espécie nativa do Brasil (do Estado Minas Gerais ao Rio Grande do Sul) (Marchiori 1996). No Parque Ibirapuera foi registrada 
nos setores 5, 8, 10, 28, 46. No município de São Paulo foi registrada também nos parques Luz (Hashimoto 1988) e Independência Almeida et al. (2010).

\section{Aspectos florísticos, quantitativos e conservação}

Em todo o Parque Ibirapuera foram identificadas 20 espécies de Gimnospermas, pertencendo a 13 gêneros distribuídos em cinco famílias. A família com maior riqueza em relação a número de espécies foi Cupressaceae (nove espécies), seguida de Araucariaceae e Pinaceae (quatro espécies cada), Cycadaceae (duas espécies) e Podocarpaceae (uma espécie). Em relação ao último levantamento realizado no Parque (Hashimoto 1988) houve um aumento de $11,1 \%$ na riqueza.

Registrou-se um total de 352 indivíduos distribuídos por 35 setores do Parque. Na figura 3 são apresentadas as quantidades de indivíduos e número de setores de ocorrência. Pinus elliottii foi a espécie que apresentou o maior número de indivíduos (105), seguida por Araucaria angustifolia (59); enquanto Araucaria heterophylla foi a espécie com ocorrência em maior número de setores (11), seguida por Cryptomeria japonica (oito). Pinus elliottii e Araucaria angustifolia se destacam no Parque também por formar bosques quase monoespecíficos, respectivamente nos setores 8 e 58 .

Das 20 espécies ocorrentes no Parque, somente duas são nativas no Brasil, Araucaria angustifolia e Podocarpus lambertii. Dessas duas, apenas a primeira tem ocorrência natural no município de São Paulo. Sendo assim, seria interessante a introdução da outra espécie nativa no município, Podocarpus sellowii Klotzsch ex Endl., o que contribuiria para sua divulgação e conservação. Dos 352 indivíduos do Parque, apenas 66 indivíduos são de espécies nativas do Brasil (e destes, apenas 60 de espécies nativas do município de São Paulo), ou seja, $18,75 \%$ dos indivíduos do Parque são de espécies nativas do Brasil e $81,25 \%$ de exóticas. Considerando que $39,4 \%$ dos 15.055 exemplares arbóreos cadastrados no Parque são de espécies nativas do Brasil (Kabashima et al. 2011), nota-se que a proporção de espécies de Gimnospermas exóticas no Parque é grande, embora represente apenas cerca de 3\% dos exemplares de espécies exóticas do Parque.

De acordo com os levantamentos florísticos realizados em 30 localidades do município de São Paulo, incluindo parques e reservas, 21 apresentaram registros de Gimnospermas (Hoehne et al. 1941, Hashimoto 1988, Garcia 1999a, Garcia 1999b, Garcia \& Pirani 2001, Garcia \& Pirani 2005, Lagoa 2008, Souza et al. 2009, Almeida et al. 2010) (figura 4). Dentre estes, os cinco locais com maior número de espécies de Gimnospermas foram o Parque Ibirapuera (20 espécies), seguido pelo Parque da Luz (13), Parque do Carmo (10), Jardim Botânico (oito) e o Parque Piqueri (sete). As cinco espécies com maior ocorrência foram Araucaria angustifolia (em 16 localidades), seguida por Cryptomeria japonica (11), Pinus elliottii (nove), Cupressus sempervirens (seis) e Platycladus orientalis (cinco). As três espécies brasileiras apresentaram as seguintes ocorrências: Araucaria angustifolia em 16 localidades, Podocarpus sellowii e Podocarpus lambertii, em quatro cada uma.

Entretanto, oito locais com levantamentos não registraram nenhuma gimnosperma: Parque Alfredo Volpi (Aragaki 1997, Hashimoto 1988), Parque Ecológico Guarapiranga (Lieberg 2003), Parque Ecológico Tietê (Dorado 1992), Parque Estadual da Cantareira (Baitello \& Aguiar 1982, Baitello et al. 1992), Parque Estadual Urbano Fazenda TIZO (Costa 2006), Reserva da CUASO (Rossi 1994), Parque Tenente Siqueira Campos (Hashimoto 1988) e SESC Interlagos (Pagano et al. 1999).

O Parque Ibirapuera, além de apresentar a maior riqueza de Gimnospermas dentre as localidades analisadas, apresenta também duas espécies de ocorrência exclusiva, Callitris oblonga e Cupressus macnabiana. Apenas oito espécies encontradas nas outras localidades não estão presentes no Parque Ibirapuera: Encephalartos hildebrandtii A. Braun \& Bouché-Zamiaceae; Ginkgo biloba L. -Ginkgoaceae; Chamaecyparis pisifera (Siebold \& Zucc.) Endl. e Cupressus lusitanica Mill. - Cupressaceae; Pinus canariensis C. Smith in Buch e Pinus patula Schltdl. \& Cham. - Pinaceae e Podocarpus sellowii Podocarpaceae. Dessas, apenas a última é nativa do Brasil e registrada para o Parque Estadual da Serra do Mar - Núcleo Curucutu, para o Jardim Botânico de São Paulo, Reserva do Parque Estadual das Fontes do Ipiranga e para o Parque Santo Dias.

De acordo com os dados apresentados por Hashimoto (1988), das 16 espécies ocorrentes no Parque Ibirapuera, presentes no levantamento de 1988, quatro não foram encontradas durante o desenvolvimento do presente trabalho - Ginkgo biloba, Araucaria columnaris, Cupressus lusitanica e Chamaecyparis pisifera - possivelmente devido à morte dos espécimes ou identificação errônea à época. 


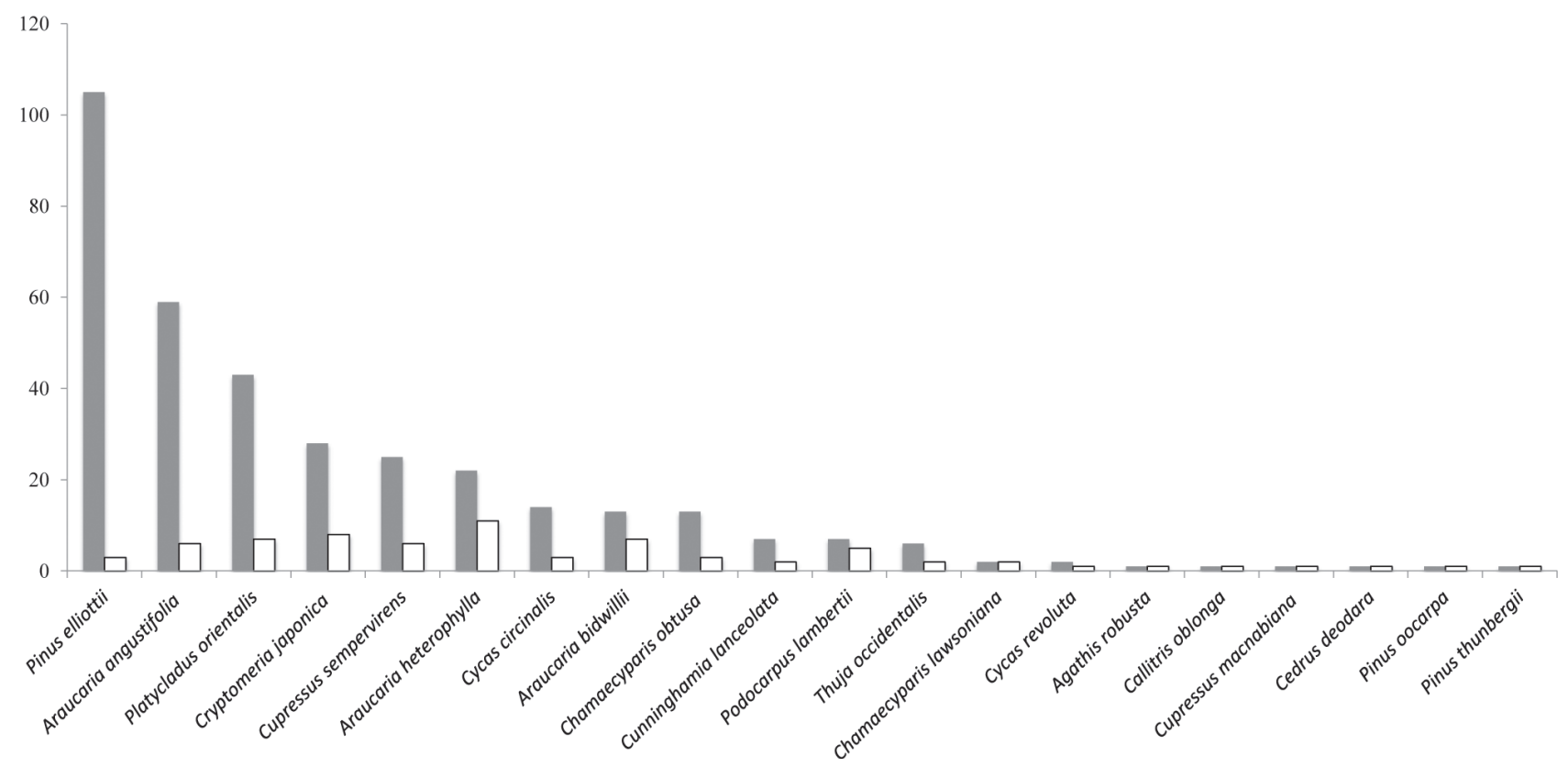

Figura 3. Quantidade de indivíduos e setores de ocorrência das espécies de Gimnospermas do Parque Ibirapuera, São Paulo, SP, Brasil.

$\square$ Número de indivíduos, $\square$ Qualidade de setores com ocorrência.

Figure 3. Number of individuals and sectors of occurrence of the Gymnosperm species of Parque Ibirapuera, São Paulo, São Paulo State, Brazil. $\square$ Number of individuals, $\square$ Amount of sectors with occurrence.

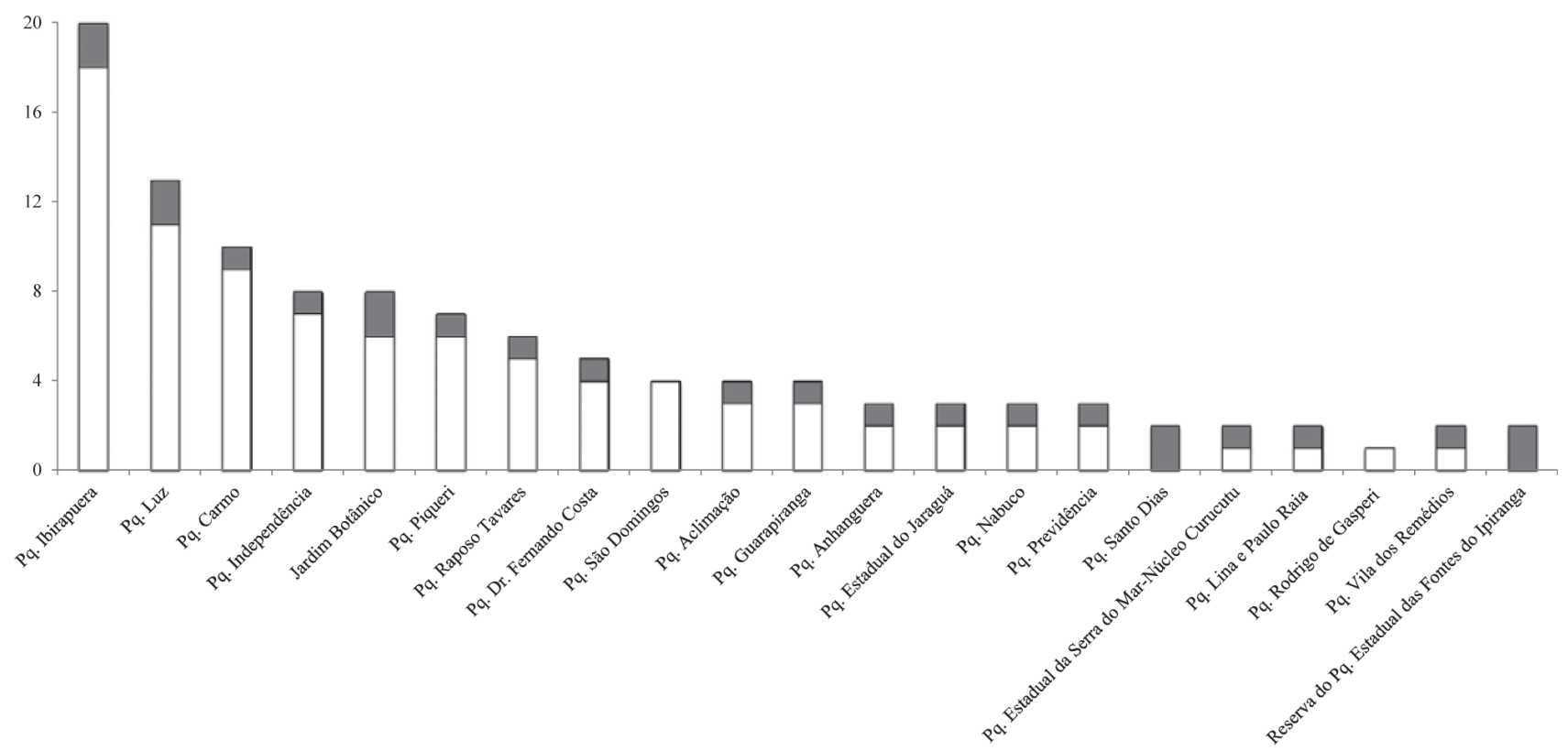

Figura 4. Riqueza de Gimnospermas em áreas com levantamentos no município de São Paulo, São Paulo State, Brazil. $\square$ Nativas do Brasil, $\square$ Exóticas.

Figure 4. Richness of Gymnosperms in areas with surveys in São Paulo city, São Paulo State, Brazil. $\square$ Native of the Brazil, $\square$ Exotic. 
Por outro lado, verificou-se no presente trabalho que quatro espécies não constam do levantamento de Hashimoto (1988) para o Parque Ibirapuera: Agathis robusta, Callitris oblonga, Cupressus macnabiana e Cedrus deodara, um incremento de $20 \%$ na riqueza de Gimnospermas em relação ao levantamento de Hashimoto (1988) para o Parque Ibirapuera. Tais dados mostram a necessidade de uma periódica atualização das listas de espécies dos parques municipais.

Um aspecto de relevante interesse para as atividades educativas é a constatação da presença no Parque de cinco dentre as 10 espécies mais importantes quanto à área de cobertura em reflorestamentos no Estado de São Paulo (Kronka et al. 2005) - Pinus elliottii, Pinus oocarpa, Araucaria angustifolia, Cunninghamia lanceolata e Cryptomeria japonica. Estes dados possibilitam, por exemplo, a discussão sobre o uso de espécies nativas em atividades econômicas (apenas Araucaria angustifolia), bem como o potencial de invasão biológica que representam (como Pinus elliottii em áreas campestres).

De acordo com os dados apresentados, verificou-se que o Parque Ibirapuera tem uma grande importância para o estudo e conservação das Gimnospermas, pois dentre as 30 localidades do município de São Paulo analisadas, ele apresentou a maior riqueza, com 20 espécies, sete a mais que o segundo colocado (Parque da Luz). Também merece destaque, a ocorrência de seis espécies que se constituem no primeiro registro publicado para o município de São Paulo: Callitris oblonga Chamaecyparis lawsoniana, Chamaecyparis obtusa, Cupressus macnabiana e Thuja occidentalis - Cupressaceae e Pinus oocarpa - Pinaceae. Essa riqueza encontrada no Parque Ibirapuera representa um importante tipo de conservação ex situ das Gimnospermas, o que ajuda na conservação do patrimônio genético dessas plantas. Exemplo disso foi o uso de matrizes do Parque para coleta de sementes visando à produção de mudas de Araucaria angustifolia e Cupressus sempervirens (Penha 2014).

O Parque Ibirapuera tem sido um local de destaque para atividades de divulgação científica e educação ambiental, no qual as Gimnospermas podem ocupar papel de destaque, seja em atividades individuais como percursos auto-guiados (placas e publicações de divulgação), seja em atividades coletivas, como aulas de cursos de jardinagem e de recursos paisagísticos, além de visitas monitoradas.

Dentre as 60 espécies de Gimnospermas indicadas para uso em paisagismo (Lorenzi \& Souza 2001,
Lorenzi 2002, 2003), o Parque do Ibirapuera apresenta 16 espécies, o que evidencia a sua importância para estudos paisagísticos. Ou seja, a realização de uma visita ao Parque permite o reconhecimento em campo de situações com utilização paisagística de 26,6\% das espécies indicadas desse grupo de plantas. $\mathrm{Na}$ figura 2 são indicados espécimes significativos (um de cada espécie), para uso em atividades educativas e de divulgação.

Quanto ao estado de conservação das Gimnospermas do Parque Ibirapuera, não se observou manejo inadequado, fato que contrasta com o observado para as palmeiras do Parque (Pena 2003), em que tais interferências dificultaram inclusive a identificação das espécies. Porém, o uso paisagístico das Gimnospermas está mal explorado no Parque, pois muitas espécies estão plantadas em bosques heterogêneos, competindo com outras plantas por espaço e visibilidade, o que minimiza o efeito ornamental dessas plantas.

Seria interessante que futuros projetos de manejo do Parque visassem melhorar o potencial paisagístico das Gimnospermas, dado o caráter ornamental do grupo. Algumas medidas tomadas nos últimos anos já trouxeram melhorias nesse sentido, como a substituição de calçadas cimentadas por gramados e a substituição do sistema de iluminação (antes com fiação aérea) com enterramento da rede elétrica.

\section{Agradecimentos}

Os autores agradecem ao Vicente Almeida Sampaio Teixeira, no trabalho de campo; à Graça Maria Pinto Ferreira, por todo o apoio na fase laboratorial; e ao Marcos Kawall Vasconcellos pela revisão das figuras. O primeiro Autor agradece à Prefeitura do Município de São Paulo, pela bolsa concedida.

\section{Literatura citada}

Almeida, R.F., De Sordi, S.J. \& Garcia, R.J.F. 2010. Aspectos florísticos, históricos e ecológicos do componente arbóreo do Parque da Independência, São Paulo, SP. Revista SBAU 5: 18-41.

Aragaki, S. 1997. Florística e estrutura de trecho remanescente de floresta no Planalto Paulistano (SP). São Paulo. Dissertação de Mestrado, Universidade de São Paulo, São Paulo.

Baitello, J.B. \& Aguiar, O.T. 1982. Flora arbórea da Serra da Cantareira (São Paulo). Silvicultura em São Paulo 16: $582-590$. 
Baitello, J.B., Aguiar, O.T., Rocha, F.T., Pastore, J.A. \& Esteves, R. 1992. Florística e fitossociologia do estrato arbóreo de um trecho da Serra da Cantareira (Núcleo Pinheirinho)-SP. Revista do Instituto Florestal 4: 291-297.

Burleigh, J.G. \& Mathews, S. 2004. Phylogenetic signal in nudeotide data from seed plants: Implications for resolving the seed plant tree of life. American Journal of Botany 91: 1599-1613.

Chaw, S.M., Parkinson, C.L., Chen, Y., Vincent, T.M. \& Palmer, J.D. 2000. Seed plant phylogeny inferred from all three plant genomes: Monophyly of extant gymnosperms and origin of Gnetales from conifers. Proceedings of the Academy of Sciences of the United States of American 97: 4086-4091.

Costa, R. 2006. Impactos sobre remanescentes de florestas de mata atlântica na zona oeste da Grande São Paulo: um estudo de caso da mata da Fazenda TIZO. Dissertação de Mestrado, Universidade de São Paulo, São Paulo.

Dallimore, W. \& Jackson, A.B. 1966. A Handbook of Coniferae and Ginkgoaceae. Edward Arnold, London.

Doley, J.A. 2006. Seed ferns and the origin of angiosperms. Journal of the Torrey Botanical Society Club 133: 169-209.

Dorado, A.J. 1992. Planificação ambiental no Parque Ecológico do Tietê, na Região Metropolitana de São Paulo. Dissertação de Mestrado, Universidade de São Paulo, São Paulo.

Farjon, A. \& Styles, B.T. 1997. Pinus (Pinaceae). The New York Botanical Garden, New York. (Flora Neotropica, monograph 75).

Fidalgo, O. \& Bononi, V.L.R. 1989. Técnicas de coleta, preservação e herborização de material botânico. Instituto de Botânica, São Paulo.

Garcia, R.J.F. 1999a. Flora Fanerogâmica da Reserva do Parque Estadual das Fontes do Ipiranga (São Paulo, Brasil), 199 - Araucariaceae. Hoehnea 26: 103-104.

Garcia, R.J.F. 1999b. Flora Fanerogâmica da Reserva do Parque Estadual das Fontes do Ipiranga (São Paulo, Brasil), 200 - Podocarpaceae. Hoehnea 26: 105-106.

Garcia, R.J.F. 2002. Araucariaceae. In: M.G.L. Wanderley, G.J. Shepherd, A.M. Giulietti, T.S. Melhem, V. Bittrich \& C. Kameyama (eds.). Flora Fanerogâmica do Estado de São Paulo. vol.2. FAPESP / Hucitec, São Paulo, pp. 1-2.

Garcia, R.J.F. \& Pirani, J.R. 2001. Estudo florístico dos componentes arbóreo e arbustivo da mata do Parque Santo Dias, São Paulo, SP, Brasil. Boletim de Botânica da Universidade de São Paulo 19: 15-42.

Garcia, R.J.F. \& Pirani, J.R. 2005. Análise florística, ecológica e fitogeográfica do Núcleo Curucutu, Parque Estadual da Serra do Mar (São Paulo, SP), com ênfase nos campos junto à crista da Serra do Mar. Hoehnea 32: $1-48$.
Hashimoto, G. 1988. Conheça o Verde. Centro de Pesquisas de História Natural, São Paulo.

Hoehne, F.C., Kuhlmann, M. \& Handro, O.O. 1941. O Jardim Botânico do Estado de São Paulo. Departamento de Botânica do Estado, São Paulo.

Kabashima Y., Andrade, M.L.F., Gandara, F.B., Tomas, F.L., Polizel, J.L., Velasco, G.D.N., Silva, L.F., Dozzo, A.D.P., Moura, R.G. \& Silva Filho, D.F. 2011. Histórico da composição da vegetação arbórea do Parque do Ibirapuera e sua contribuição para a conservação da biodiversidade. Revista SBAU 6: $125-144$.

Kronka, F.J.N., Nalon, M.A., Matsukuma, C.K., Kanashiro, M.M., Iwane, M.S.S., Pavão, M., Durigan, G., Lima, L.M.P.R., Guillaumon, J.R. \& Baitello, J.B. 2005. Inventário florestal da vegetação natural do Estado de São Paulo. Secretaria do Meio Ambiente e Instituto Florestal. Imprensa Oficial, São Paulo.

Lagoa, M.H.B. 2008. O Parque da Água Branca: o manejo sustentável de uma floresta urbana. Dissertação de Mestrado, Universidade de São Paulo, São Paulo.

Lieberg, S. A. 2003. Análise sucessional de fragmentos florestais urbanos e delimitações de trilhas como instrumento de gestão e manejo no programa de uso público do Parque Ecológico do Guarapiranga, São Paulo. Rio Claro. Tese de Doutorado, Universidade Estadual Paulista, Rio Claro.

Lorenzi, H. 2002. Árvores brasileiras: manual de identificação e cultivo de plantas arbóreas do Brasil, volume 1, 2 ed. Instituto Plantarum, Nova Odessa.

Lorenzi, H. 2003. Árvores exóticas no Brasil: madeiras, ornamentais e aromáticas. Instituto Plantarum, Nova Odessa.

Lorenzi, H. \& Souza, H.M. 2001. Plantas ornamentais no Brasil: arbustivas, herbáceas e trepadeiras. 3 ed. Instituto Plantarum, Nova Odessa.

Marchiori, J.N.C. 1996. Dendrologia das Gimnospermas. Editora da Universidade Federal de Santa Maria, Santa Maria.

Mattos, J.R. 1998. Espécies de Pinus cultivadas no Brasil. Chácaras e Quintais, s.l.

Pagano, N.S., César, O., Furlan, A. \& Manzatto, G.A. 1999. Composição florística e estrutura fitossociológica do estrato arbóreo da Mata Atlântica do SESC Interlagos. In: SESC Interlagos - de Centro Campestre a Ilha Verde na Cidade. Centro de Artes Gráficas do SESC, São Paulo, pp 12-44.

Pena, A.M. 2003. Estudo florístico e quantitativo das palmeiras (Palmae) do Parque Ibirapuera, São Paulo. São Paulo. Monografia de Graduação em Ciências Biológicas, Universidade de Santo Amaro, São Paulo. 
Penha, N.M.E. 2014. Análise das espécies do componente arbóreo produzidas pela Prefeitura do Município de São Paulo. Monografia de Graduação em Biologia, Centro Universitário Adventista de São Paulo, São Paulo.

Rossi, L. 1994. A flora arbóreo-arbustiva da mata da Reserva da Cidade Universitária "Armando de Salles Oliveira" (São Paulo, Brasil). Boletim do Instituto de Botânica 9: 1-105.

Rydin, C., Kallersjo, M. \& Friis, E.M. 2002. Seed plant relationships and the systematic position of Gnetales based on nuclear and chloroplast DNA: Conflicting data, rooting problems, and the monophyly of conifers. International Journal of Plant Sciences 163: 197-214.

Souza, F.M., Sousa, R.C., Esteves, R. \& Franco, G.A.D.C. 2009. Flora arbustivo-arbórea do Parque Estadual do Jaraguá, São Paulo-SP. Biota Neotropica 9: 187-200.
Souza, V.C. 2012. Gimnospermas. In: R.C. Forzza, J.F.A. Baumgratz, C.E.M. Bicudo, A.A. Carvalho Jr., A. Costa, D.P. Costa, M. Hopkins, P.M. Lettman, L.G. Lohmann, L.C. Maia, G. Martinelli, M. Menezes, M.P. Morim, M.A.N. Coelho, A.L. Peixoto, J.R. Pirani, J. Prado, L.P. Queiroz, V.C. Souza, J.R. Stehmann, L.S. Sylvestre, B.M.T. Walter \& D. Zappi (eds.). Lista de Espécies da Flora do Brasil. Jardim Botânico do Rio de Janeiro. Disponível em http://floradobrasil.jbrj.gov.br/ jabot/floradobrasil/FB128477(acesso em 23-VII-2014).

SVMA. 2012. Guia dos parques municipais de São Paulo. 3 ed. Secretaria Municipal do Verde e do Meio Ambiente, São Paulo.

Vidaković, M. 1991. Conifers - morphology and variation. 2 ed. Ed. Grafički Zavod, Hrvatske.

Xi, Z., Rest, J.S. \& Davis, C.C. 2013. Phylogenomics and coalescent analyses resolve extant seed plant relationships. PLoS ONE 8(11): e80870. 